\title{
Long term follow up of persistent hyperinsulinaemic hypoglycaemia of infancy
}

\author{
J C Cresto, J P Abdenur, I Bergada, R Martino
}

\begin{abstract}
Twenty six children with hypoglycaemia were diagnosed and followed between 1975 and 1995. Diagnosis was confirmed by a high insulin:glucose ratio, and low free fatty acid and 3-hydroxybutyrate on fasting. All patients were treated with diazoxide at a maximum dose of $20 \mathrm{mg} / \mathrm{kg} / \mathrm{day}$. Requirement of a higher dose was considered as a failure of medical treatment and an indication for surgery. Sixteen children responded to diazoxide; 10 failed to respond and underwent pancreatic resection. Six of the latter group started with symptoms in the neonatal period. Eleven of the 26 children have neurological sequelae. Head growth and neurological outcome correlated well. Additionally, non-specific electroencephalogram abnormalities (slow waves) appear to be indicative of subclinical hypoglycaemia during follow up.

(Arch Dis Child 1998;79:440-444)
\end{abstract}

Keywords: persistent hyperinsulinaemic hypoglycaemia of infancy; diazoxide treatment; head growth

Hypoglycaemia in the newborn and during the first year of life from whatever cause usually responds rapidly to intravenous glucose. ${ }^{1}$ Nevertheless, there is a small group of patients with hyperinsulinism, who experience severe hypoglycaemia and who are difficult to treat. Outcome may be suboptimal in these patients, especially if the diagnosis is delayed or treatment unsuccessful. These patients have been characterised as having "persistent hyperinsulinaemic hypoglycaemia of infancy" (PHHI). ${ }^{2}$ The histological basis of the disease has been defined as "nesidioblastosis", "diffuse cell hyperplasia", or "islet cells dysmaturation syndrome". ${ }^{3-6}$

The diagnosis of PHHI is usually made following recurrent hypoglycaemic episodes that occur after a short period of fasting in a child who otherwise appears normal. A low blood sugar associated with inappropriately high insulin (high insulin:glucose ratio), and/or C-peptide, and low free fatty acids and 3-hydroxybutyrate concentrations confirms the diagnosis. The requirement of a high glucose infusion rate to control hypoglycaemia is also characteristic. ${ }^{27}$

The cause of PHHI is unknown. Some patients with a familial form of the disease have abnormalities in the sulfonylurea receptor gene. ${ }^{8}$ In others it has been postulated that they have a disturbance in the endocrine prolifera- tion of fetal pancreas ${ }^{6}$ or an alteration in insulin secretion.

Initial treatment is with glucose and sometimes with steroids; long term hypoglycaemic control involves frequent feeding, controlled protein intake, diazoxide, and/or somatostatin. Several published series of patients with PHHI, treated long term with diazoxide or octreotide, have emphasised how difficult it is to obtain a normal outcome. ${ }^{10-12}$ Some patients with poor response to medical treatment require surgery (near total pancreatectomy).

There is limited information available on long term outcome of patients with PHHI. We report our experience of long term care of 26 children with PHHI treated with diazoxide alone, or diazoxide followed by surgery.

\section{Patients and methods}

We investigated 26 patients (16 boys, 10 girls) with PHHI diagnosed between 1975 and 1995. Twenty two were born with normal weight for gestasional age and four weighed more than $4000 \mathrm{~g}$ (table 1). There was no family history of hypoglycaemia among 41 siblings, including one non-identical twin girl. Hypoglycaemia was first documented during the first week of life in nine patients, and between 30 and 386 days in 17 patients. In the former, PHHI was confirmed at a mean (SD) age of 41 (33) days. The latter were diagnosed between 3 months and 5 years of age (table 1 ).

All underwent a fasting tolerance test which was discontinued when the patient became symptomatic and/or had a blood sugar concentration of $2.2 \mathrm{mmol} / \mathrm{l}$ or below. At the end of the fast, blood was obtained to measure insulin, glucose, C-peptide, free fatty acid and 3-hydroxybutyrate. The insulin:glucose ratio was calculated as $\mathrm{pmol} / 1$ insulin:mmol/1 glucose. A ratio less than 40 was considered normal and more than 100 was considered diagnostic of hyperinsulinism. Values between 40 and 100 were considered suggestive of PHHI. All patients underwent regular clinical review and measurement of insulin:glucose ratio and, when possible, free fatty acids and 3-hydroxybutyrate.

Normal values for glucose and insulin were obtained from 30 normal infants (16 boys, 14 girls) after an overnight fast.

Blood glucose was measured by glucose oxidase, insulin by radioimmunoassay with the charcoal dextran technique, ${ }^{13}$ and C-peptide by radioimmunoassay as described by Heding. ${ }^{14}$ C-peptide standard and antiserum was a gift from Dr H Frank from Eli Lilly Co (Indianapolis, USA). Free fatty acids were determined with a modified Ducombe technique, ${ }^{15}$ and 
Table 1 Clinical data

\begin{tabular}{|c|c|c|c|c|c|c|c|c|c|c|c|c|c|c|}
\hline Patient & $\begin{array}{l}\text { Birth- } \\
\text { weight } \\
\text { (g) }\end{array}$ & Sex & $\begin{array}{l}\text { Age of } \\
\text { documented } \\
\text { hypoglycaemia } \\
\text { (days) }\end{array}$ & $\begin{array}{l}\text { Age when } \\
\text { PHHI } \\
\text { diagnosed } \\
\text { (days) }\end{array}$ & $\begin{array}{l}\text { Diazoxide } \\
\text { (mg/kg/ } \\
\text { day) }\end{array}$ & Prednisone & Somatostatin & Octeotride & $\begin{array}{l}\text { Treatment } \\
\text { with } \\
\text { diazoxide }\end{array}$ & $\begin{array}{l}\text { Pancreat- } \\
\text { ectomy }\end{array}$ & $\begin{array}{l}\text { Age } \\
\text { treatment } \\
\text { discontinued }^{\star}\end{array}$ & $\begin{array}{l}\text { SDS of } \\
\text { height }\end{array}$ & $\begin{array}{l}\text { SDS of } \\
\text { weight }\end{array}$ & Sequelae \\
\hline 1 & 4300 & M & 1 & 120 & 16 & Yes & No & No & 7 y $10 \mathrm{~m}$ & - & - & -0.69 & -0.81 & SZ \\
\hline 2 & 3500 & $\mathrm{~F}$ & 1 & 26 & 20 & Yes & No & No & $18 \mathrm{~m}$ & No & 1 y $8 \mathrm{~m}$ & 1.11 & 1.44 & None \\
\hline 3 & 2800 & $M$ & 1 & 45 & 20 & Yes & No & No & $2 \mathrm{~m}$ & $\begin{array}{l}95 \% \\
100 \%\end{array}$ & $5 \mathrm{~m}$ & -0.06 & 0.85 & $\mathrm{SZ}$ \\
\hline 4 & 3300 & M & 1 & 14 & 12 & No & Yes & No & $1 \mathrm{~m}$ & $95 \%$ & $2 \mathrm{~m}$ & 0.14 & -0.17 & None \\
\hline 5 & 4100 & $\mathrm{~F}$ & 4 & 35 & $\begin{array}{l}20 \\
20\end{array}$ & $\begin{array}{l}\text { Yes } \\
\text { Yes }\end{array}$ & $\begin{array}{l}\text { Yes } \\
\text { Yes }\end{array}$ & $\begin{array}{l}\text { No } \\
\text { No }\end{array}$ & $\begin{array}{l}2 \mathrm{~m} \\
3 \mathrm{~m}\end{array}$ & $\begin{array}{l}70 \% \\
95 \% \\
100 \%\end{array}$ & $6 \mathrm{~m}$ & -0.27 & -0.21 & $\begin{array}{l}\text { SZ } \\
\text { ST } \\
\text { IDDM }\end{array}$ \\
\hline 6 & 4800 & M & 2 & 53 & 20 & No & No & No & $3 \mathrm{~m}$ & $95 \%$ & $5 \mathrm{~m}$ & -0.23 & -0.82 & None \\
\hline 7 & 4000 & $\mathrm{~F}$ & 1 & 44 & 25 & Yes & No & No & $4 \mathrm{~m}$ & $95 \%$ & $5 \mathrm{~m}$ & 1.7 & 0.2 & $\mathrm{BD}$ \\
\hline 8 & 3300 & M & 3 & 10 & 7.5 & No & No & No & $4 \mathrm{~m}$ & No & $4 \mathrm{~m}$ & -0.08 & -0.39 & None \\
\hline 9 & 3900 & $\mathrm{M}$ & 1 & 20 & 20 & No & Yes & No & $1 \mathrm{~m} \dagger$ & $95 \%$ & & -0.69 & -0.21 & None \\
\hline 10 & 2700 & M & 150 & 300 & 15 & Yes & No & No & 16 y $6 \mathrm{~m}$ & $95 \%$ & $19 \mathrm{y}$ & 1.31 & 0.45 & SMD-ST \\
\hline 11 & 3700 & M & 60 & 90 & 15 & Yes & No & No & 15 y $9 \mathrm{~m}$ & $95 \%$ & $16 \mathrm{y}$ & 0.58 & 0.07 & SMD \\
\hline 12 & 3200 & $\mathrm{~F}$ & 365 & 2400 & 10 & No & No & No & 8 у 2 m & No & 14 y $9 \mathrm{~m}$ & 0.08 & 0.36 & None \\
\hline 13 & 3400 & M & 302 & 366 & 7 & Yes & No & No & $7 \mathrm{y}$ & No & $9 \mathrm{y}$ & 0.73 & 0.31 & None \\
\hline 14 & 3100 & $\mathrm{~F}$ & 334 & 448 & 12 & Yes & No & No & 9 y $3 \mathrm{~m}$ & No & 10 y $6 \mathrm{~m}$ & -0.52 & 0.21 & None \\
\hline 15 & 3800 & M & 80 & 107 & 12 & Yes & No & No & 1 y $5 \mathrm{~m}$ & $95 \%$ & 1 y $5 \mathrm{~m}$ & 1.62 & 1.32 & $\mathrm{BD}$ \\
\hline 16 & 3900 & M & 63 & 155 & 10 & Yes & No & No & 3 y 7 m & No & $4 \mathrm{y}$ & 0.23 & -0.12 & None \\
\hline 17 & 3500 & M & 147 & 178 & 14 & Yes & No & No & 13 у $6 \mathrm{~m} \dagger$ & No & & -1.59 & -0.67 & None \\
\hline 18 & 3800 & $\mathrm{~F}$ & 135 & 428 & 12 & No & No & No & 13 yt & No & & 0.43 & 0.54 & SZ \\
\hline 19 & 3400 & M & 150 & 216 & 12 & Yes & No & No & 2 y $7 \mathrm{~m}$ & - & - & 0.17 & -0.23 & None \\
\hline 20 & 3200 & $\mathrm{~F}$ & 330 & 330 & 19 & No & No & No & 4 y $3 \mathrm{~m}$ & - & - & -1.58 & -1.76 & $\mathrm{BD}$ \\
\hline 21 & 2500 & $\mathrm{~F}$ & 120 & 150 & 10 & No & No & No & 7 y† & No & & 0.79 & 0.22 & None \\
\hline 22 & 4400 & $\mathrm{~F}$ & 120 & 189 & 12 & No & No & No & $2 \mathrm{y}$ & No & 2 y $6 \mathrm{~m}$ & -0.16 & -0.69 & None \\
\hline 23 & 3100 & $\mathrm{~F}$ & 210 & 273 & 11 & No & No & No & 7 y $5 \mathrm{~m} \dagger$ & No & & -0.1 & -0.17 & None \\
\hline 24 & 4000 & M & 163 & 337 & 10 & Yes & No & No & 6 y $11 \mathrm{~m} \dagger$ & No & & -0.81 & -0.64 & None \\
\hline 25 & 2800 & M & 386 & 410 & 11 & No & No & No & 7 y $8 \mathrm{~m} \dagger$ & No & & -2.24 & -2.06 & None \\
\hline 26 & 3100 & $M$ & 90 & 120 & 10 & No & No & Yes & $10 \mathrm{~m}$ & $95 \%$ & 1 y $7 \mathrm{~m}$ & -1.01 & -1.11 & $\mathrm{BD}$ \\
\hline
\end{tabular}

*When hypoglycaemia resolved; †continues with diazoxide; - lost to follow up.

SMD, slight motor disability; SZ, seizures; BD, brain damage (diffuse cortical atrophy with enlarged ventricular system); ST, steatorrhoea; IDDM, insulin dependent diabetes mellitus.

3-hydroxybutyrate was determined with an enzymatic procedure. ${ }^{16}$ Values for free fatty acids and 3-hydroxybutyrate obtained during the fasting test were compared to those reported by Bonefont and colleagues. ${ }^{17}$

Follow up assessments included growth, intellectual performance (using the Briac, Termen, Gesell and WISC (Weschler infantile scale coefficient) test), school performance, and metabolic status with an overnight fasting test. Head circumference was followed with the Nellhaus chart. An electroencephalogram (EEG) was performed annually or when requested by a paediatric neurologist.

Student's $t$ test for paired samples was used for statistical comparisons.

Results

The insulin:glucose ratio was high during fasting and was also high when C-peptide was converted to equivalent insulin. Free fatty acids and 3-hydroxybutyrate values were low in relation to glucose level and were also low for a normal population of identical age and fasting. Laboratory results obtained during the fasting test are shown in table 2 and the insulin:glucose ratio in fig 1.

In one child (patient 18) the insulin:glucose ratio was less than 40 because the fasting test was performed while the patient was already on

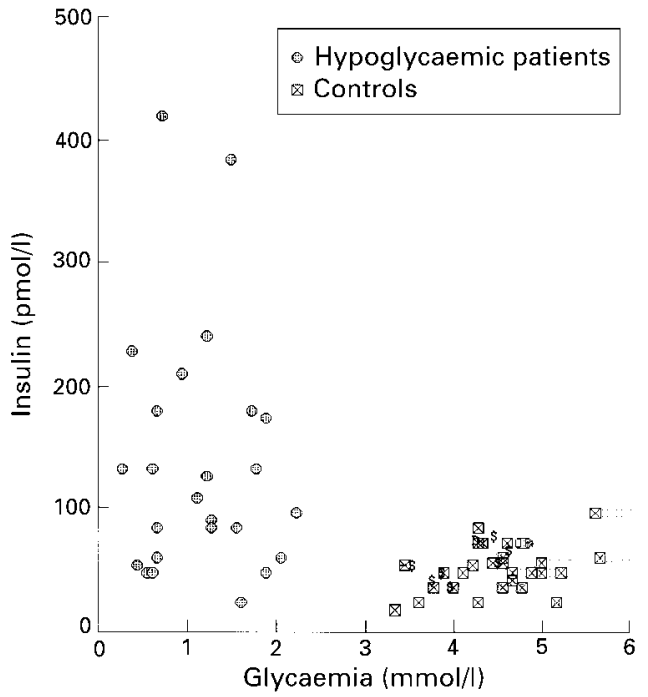

Figure 1 Comparison of hyperinsulinaemic hypoglycaemia with normal controls. Insulin $v$ glucose after variable fasting in hyperinsulinaemic and normal children.

treatment with diazoxide. This patient had been referred from another hospital with documented hypoglycaemia requiring a high rate of glucose infusion, typical of PHHI.

All patients began diazoxide treatment as soon as the diagnosis was established. Fourteen

Table 2 Results of the fasting test in hypoglycaemic children before treatment

\begin{tabular}{lllllllll}
\hline & $\begin{array}{l}\text { Glucose } \\
\text { (mmol/l) }\end{array}$ & $\begin{array}{l}\text { Insulin } \\
\text { (pmol/l) })\end{array}$ & $\begin{array}{l}\text { C-peptide } \\
\text { (pmol/l) }\end{array}$ & $\begin{array}{l}\text { Free fatty acids } \\
\text { (mmol/l) }\end{array}$ & $\begin{array}{l}\text { 3-OH-butyrate } \\
\text { (mmol/l) }\end{array}$ & $\begin{array}{l}\text { Insulin/ } \\
\text { glucose }\end{array}$ & $\begin{array}{l}{ }^{*} \text { C-peptidel } \\
\text { glucose }\end{array}$ & $\begin{array}{l}\text { Fasting } \\
\text { (hours) }\end{array}$ \\
\hline Mean & 1.16 & 132.6 & 68.8 & 0.36 & 0.07 & 159.13 & 252.4 & 7.1 \\
SD & 0.57 & 100.2 & 75.6 & 0.23 & 0.04 & 163.9 & 292.8 & 5.1 \\
$\mathrm{n}$ & 26 & 26 & 5 & 12 & 12 & 26 & 5 & 26
\end{tabular}

Insulin/glucose in normal controls is 11.45 (3.89).

^Insulin equivalent. 
patients had already received steroids. Somatostatin or octreotide were used in patients who did not respond to diazoxide and before surgery (table 1). Diazoxide was increased from $5-10 \mathrm{mg} / \mathrm{kg} /$ day until a normal fasting glucose was reached with normal insulin:glucose ratio, or a maximum dose was reached of $20 \mathrm{mg} / \mathrm{kg}$ /day. In one patient (patient 7) a dose of $25 \mathrm{mg} / \mathrm{kg} /$ day was used, but was lowered due to encephalopathy with hypertension. The maximum dose of diazoxide used for each patient is shown in table 1 .

Diazoxide controlled hypoglycaemia in 16 patients (table 1). Seven discontinued diazoxide after four years six months (range four months to nine years three months) and are asymptomatic; six patients are continuing treatment (average nine years three months) and the remaining three patients were lost to follow up after four years 10 months of treatment (range two years seven months to seven years 10 months). Of the 16 patients who responded to diazoxide, only three had hypoglycaemia during the first week of life (table 1). In two (patients 2 and 8) diazoxide was successfully withdrawn at the age of 18 months and four months, respectively. The other patient (patient 1) was lost to follow up after seven years 10 months of treatment.

Ten patients failed to respond to diazoxide and underwent surgery. Six had their first hypoglycaemic episode during the first week of life. Ninety five per cent pancreatectomy was sufficient to control the hypoglycaemia in seven of the 10 patients. One patient (patient 9) continues to need diazoxide $(10 \mathrm{mg} / \mathrm{kg} /$ day $)$ after surgery. In the remaining two patients hypoglycaemic episodes continued after surgery, could not be controlled with diazoxide and required permanent somatostatin infusion. Eventually total pancreatectomy was performed in both.

During follow up, some patients had nonspecific changes in a previously normal EEG (slow waves), despite being asymptomatic and having normal blood sugar concentrations. We considered this represented suboptimal control; therefore, we re-evaluated these children with a repeat fasting tolerance test. Results were abnormal in four patients and their dose of diazoxide was increased. Metabolic control improved and the EEG became normal in two patients. The remaining two patients had an unusual outcome. Patient 10 was successfully maintained on diazoxide until the age of 11 years 6 months, when treatment was discontinued by his parents. He remained asymptomatic. At 14 years old an EEG showed slow waves and a repeat fasting test showed hyperinsulinism. He was restarted on diazoxide; EEG abnormalities persisted and he was operated on at 19 years old (fig 2). Patient 11 also responded initially to diazoxide. However, he needed steadily higher doses to control his hypoglycaemia and had slow waves on the EEG. He was operated on at 16 years old. In both patients the EEG became normal after surgery.

Ten patients had various neurological abnormalities (table 1) and/or low intelligence quotient (IQ). Four had an IQ less than 60.
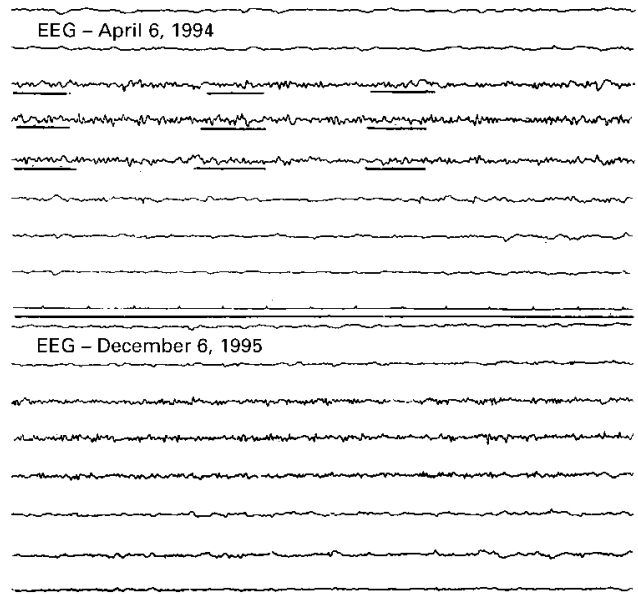

Figure 2 EEG in patient 10 before and after pancreatectomy.

One of these patients also has Turner's syndrome with $46 \mathrm{X}$ ring chromosome. Of the 10 patients with neurological impairment, seven were in the group that required surgical treatment (table 1).

Patients without neurological impairment who were treated for at least three years showed a significant improvement in their head circumference, from -0.4 to +0.6 standard deviation score (SDS) $(\mathrm{p}<0.01, \mathrm{n}=12)$. In contrast, head circumference after three years of treatment was -1.0 to -0.8 SDS (not significant, $\mathrm{n}=7$ ) in those patients who developed neurological damage such as brain atrophy on computed tomography or sequelae such as seizures, motor disabilities, and delayed maturation.

Immunohistochemistry of the pancreas in all patients who underwent surgical treatment revealed $\beta$ cell hyperplasia with an increased number and irregular distribution of islets, with endocrine cells between exocrine acini or in close contact with exocrine ducts. Hyperchromasia and/or nuclear gigantism were also present. We found no adenomas. The pathological abnormalities were similar in all patients, differing only in distribution or degree. No differences were found between those operated on as newborns or adolescents.

\section{Discussion}

All the children studied were sporadic cases with no family history of hypoglycaemia. As with other series there was no sex bias. ${ }^{18}$

We established diagnoses by the clinical picture and high insulin:glucose ratio. Hyperinsulinism should not be ruled out even in patients showing insulin:glucose values less than 40 if the clinical picture suggests this disorder. Hyperinsulinism also inhibits the normal response to hypoglycaemia, ${ }^{19}$ preventing the increase of free fatty acids and 3-hydroxybutyrate. Therefore, low free fatty acids and 3-hydroxybutyrate values associated with an abnormal insulin:glucose ratio in a child with hypoglycaemia reinforces the diagnosis of hyperinsulinism. Serum C-peptide concentration, which represents total endog- 
enous insulin secretion, is also a useful tool in diagnosing hyperinsulinism and complements venous insulin concentration, which represents the amount of insulin available after tissue extraction. $^{20}$

The description of familial forms of hyperinsulinism suggests an autosomal dominant or recessively inherited basis, ${ }^{21}$ while sporadic cases show a low prevalence of the sulfonylurea receptor gene. ${ }^{22}$

Patients differ in age of onset and severity of symptoms and response to diazoxide. Children with neonatal hypoglycaemia appear to have more severe disease than those of late onset. They respond poorly to diazoxide and have a higher rate of neurological sequelae. Nevertheless, there are exceptions. Patient 8 developed hypoglycaemia a few hours after birth and was successfully treated with diazoxide, which was withdrawn four months later without further hypoglycaemia. Landau et al described a similar patient who developed hypoglycemia on the second day of life with remission after four months. ${ }^{23}$ These patients might have "transient" hyperinsulinaemic hypoglycaemia of infancy as defined by Aynsley-Green. ${ }^{24}$

Some of our patients who responded well to diazoxide nevertheless developed neurological impairment. We attribute this outcome in three patients as due to poor treatment compliance. We attributed poor outcome in the remainder to delayed diagnosis and treatment. Our results emphasise the importance of considering whether families will comply with medical treatment when deciding on indications for surgery.

Many of our patients have been on treatment with diazoxide for many years (up to 17 years). Common side effects have been hypertrichosis and poor appetite. Only one patient became hypertensive with a dose higher than $20 \mathrm{mg} / \mathrm{kg} /$ day and we did not find haematological abnormalities or decreased serum immunoglobulins. Patients in remission after diazoxide treatment have had a normal outcome; none have developed diabetes or transient hyperglycaemia during follow up.

It has been suggested that children with PHHI may experience asymptomatic hypoglycaemia. ${ }^{25}$ These patients, who have normal blood sugar levels when studied, might present with subtle symptoms of hypoglycaemia such as learning difficulties, or non-specific signs of central nervous system involvement such as slow waves in the EEG. Although ATP concentrations significantly decrease only in extreme hypoglycaemia, ${ }^{26}$ glucose values below $2.8 \mathrm{mmol} / 1$ induce changes in evoked potentials, ${ }^{27}$ and in experimental studies blood glucose values below $2.2 \mathrm{mmol} / 1$ produce EEG changes, starting with slow waves ${ }^{28}$ According to this concept, the EEG patterns with slow waves found in our patients may be a sign of subclinical hypoglycaemia. The abnormal results of the fasting tolerance tests found in four of these patients, and the EEG improvement in two of them after increasing the dose of diazoxide, highlights the importance of these "subtle" signs of hypoglycaemia.
Head circumference appears to correlate with neurological outcome of treated children. We found statistically significant increments in head circumference in those patients with good neurological outcome. Similar results were found by Landau and colleagues, ${ }^{23}$ and Gottschalk and colleagues. ${ }^{29}$ In contrast, children with neurological abnormalities showed poorer growth in head circumference. The abnormal head growth seen in these patients could be caused by a decrease in protein synthesis, ${ }^{30}$ or by the release of neurotransmitters (such as glutamate or aspartate), and neuronal death during prolonged hypoglycaemia. ${ }^{31}$

We conclude that children with PHHI vary in clinical presentation and outcome. In those patients with neonatal onset the disease is usually more severe, so early surgery should be considered. Treatment with diazoxide at a dose less than $20 \mathrm{mg} / \mathrm{kg} /$ day appears to be safe, even when used for a long period. Follow up of these patients should include seeking "subtle" indicators of suboptimal control, such as EEG abnormalities, in order to prevent any further neurological dysfunction and/or damage.

We thank the many physicians and nurses who worked with us during this study over the past 20 years.

1 Cornblath M, Schwartz R. Disorders of carbohydrate metabolism in infancy. 3rd ed. Boston: Blackwell Scientific, 1991.

2 Daneman D, Ehrlich RM. The enigma of persistent hyperinsulinemic hypoglycemia of infancy [editorial]. F Pediatr 1993;123:573-5.

3 Heitz PU, Kloppel G, Hacki WH, Polak JM, Pearse AGE. Nesidioblastosis: the pathologic basis of persistent hyperinsulinemic hypoglycemia in infants. Diabetes 1977;26:63242 .

4 Thomas CG, Underwood LE, Carney CN, Dolcourt JL, Whitt JJ. Neonatal and infantile hypoglycemia due to insulin excess. Ann Surg 1977;185:505-17.

5 Bjerke HS, Kelly RE, Geffner ME, Fonkalsrud EW. Surgical management of islet cell dysmaturation syndrome in young children. Gynecol Obstet 1990;171:321-5.

6 Rindi G, Terenghi G, Gunilla W, Westermark P, Moscoso G, Polak JM. Islet amyloid polypeptide in proliferating pancreatic B cells during development, hyperplasia and neoplasia in humans and mice. Am ff Pathol 1991;138: 1321-34.

7 Bier DM, Leake RD, Haymond MW, et al. Measurement of "true" glucose production rates in infancy and childhood "true" glucose production rates in infancy and childh

8 Glaser B, Chiu KC, Liu L, et al. Recombinant mapping of the familial hyperinsulinism gene to a $0.8 \mathrm{~cm}$ region on chromosome 11p15.1 and demonstration of a founder effect in Ashkenazi Jews. Hum Mol Genet 1995;4:879-86.

9 Otonkoski T, Andersson S, Simell O. Somatostatin regulation of cell function in normal human fetuses and in neonates with persistent hyperinsulinemic hypoglycemia. $\mathcal{F}$ Clin Endocrinol Metab 1993;76:184-8.

10 Grant DB, Dunger DB, Burns EC. Long-term treatment with diazoxide in childhood hyperinsulinism. Acta Endocrinol 1986;279(suppl):340-5.

11 Glaser B, Hirsch HJ, Landau H. Persistent hyperinsulinemic hypoglycemia of infancy: long-term octreotide treatment without pancreatectomy. 7 Pediatr 1993;123:644-50.

12 Thornton PS, Alter CA, Levitt Katz LE, Baker L, Stanley ChA. Short- and long-term use of octreotide in the treatment of congenital hyperinsulinism. F Pediatr 1993; 123:637-43.

13 Cresto JC, Dujovne IL, Castellani PI, Mitta EA, de Majo $\mathrm{SF}$, Foglia VG. Insulin radioimmunoassay by the charcoaldextran technique. Diabetologia 1971;8:292-5.

14 Heding LG. Radioimmunological determination of human C-peptide in serum. Diabetologia 1975;11:541-8.

5 Ducombe W. The colorimetric microdetermination of long chain fatty acids. Biochem $\mathcal{F} 1963 ; 88: 7-10$.

16 Buttery JE, Chamberlain BR, Pannall PR. Colorimetric measurement of abnormal level of $\beta$-hydroxybutyrate in plasma. Clin Chem Acta 1984;139:167-71.

17 Bonnefont JP, Specola NB, Lombes A, et al. The fasting test in pediatrics. Application to the diagnosis of pathological hypo- and hyperketotic states. Eur F Pediatr 1990;150:80-5.

18 Labrune P, Bonnefont JP, Nihoul-Fekete C, et al. Evaluation des méthodes diagnostiques et thérapeutiques de l'hyperinsulinisme du nouveau-né et du nourrisson. A propos de l'étude rétrospective de 26 enfants. Arch Fr Pediatr 1989;46:167-73. 
19 Cryer PE. Glucose homeostasis and hypoglycemia. In: Wilson JD, Foster DW, eds. Williams textbook of endocrinology. .

20 Polonsky KS, Rubenstein AH. C-peptide as a measure of the secretion and hepatic extraction of insulin: pitfalls and limitations. Diabetes 1984;33:486-94.

21 Stanley ChA. Hyperinsulinism in infants and children Pediatr Clin N Am 1997;44:363-73.

22 Meissner T, Brune W, Mayatepek E. Persistent hyperinsulinaemic hypoglycemia of infancy - therapy, clinical outcome and mutational analysis. Eur F Pediatr 1997;156:7547.

23 Landau H, Perlman M, Meyer S, et al. Persistent neonatal hypoglycemia due to hyperinsulinism: medical aspects. Pediatrics 1982;70:440-6.

24 Aynsley-Green A, Soltész G. Hypoglycaemia in infancy and childhood. Edinburgh: Churchill Livingstone, 1985:65-6.

25 Baker L, Thornton PS, Stanley CA. Management of hyperinsulinism in infants [editorial]. F Pediatr 1991;119:755-7.

insulinism in infants [editorial]. F Pediatr 1991;119:755-7. Maintenance of high-energy brain phosphorous com- pounds during insulin-induced hypoglycemia in men. 31P nuclear magnetic resonance spectroscopy study.

27 Koh THHG, Aynsley-Green A, Tarbit M, Eyre JA. Neural dysfunction during hypoglycaemia. Arch Dis Child 1988;63: 1353-8.

28 Lewis LD, Ljunggren B, Ratcheson RA, Siesjo BK. Cerebral energy state in insulin-induced hypoglycemia, related to blood glucose and to EEG. $\mathcal{F}$ Neurochem 1974;23:673-9.

29 Gottschalk ME, Geffner ME, Yasuda PM, Shields WD. Reversal of microcephaly and developmental delay after cure of hyperinsulinemic hypoglycemia. F Pediatr 1990;117: 432-4.

30 Bergstedt $\mathrm{K}$, $\mathrm{Hu} \mathrm{BR}$, Wieloch $\mathrm{T}$. Initiation of protein synthesis and heat-shock protein-72 expression in the rat brain following severe insulin-induced hypoglycemia. Acta Neuropathol Berl 1993;86:145-53.

31 Auer RN, Siesjo BK. Hypoglycaemia: brain neurochemistry and neuropathology. In: Gregory JW, Ansley-Green A, eds. Hypoglycaemia. Bailliere's clinical endocrinology and metabolism 1993;7:611-25. 